\title{
SEPARATIO BONORUM - SEPARATION OF THE ESTATE FROM THE PROPERTY OF THE HEIR
}

\author{
Angel RISTOV \\ Associate Professor, University „Ss. Cyril and Methodius”, Faculty of law \\ „Iustinianus Primus”, Skopje, North Macedonia \\ E-mail: angelristov@yahoo.com \\ Dejan MICKOVIK \\ Full Professor, University „Ss. Cyril and Methodius”, Faculty of law \\ „Iustinianus Primus”, Skopje, North Macedonia \\ E-mail: dejanmickovik@yahoo.com \\ Milica SHUTOVA \\ Assistant Professor, University ,Goce Delchev” Shtip, Faculty of Law \\ E-mail: milica.sutova@ugd.edu.mk
}

\begin{abstract}
With the occurrence of a person's death, his/her legal subjectivity ends and his/her succession is opened. The deceased's property rights and obligations are transferred to his/her heirs by law. The institute separatio bonorum, separation of the estate from the property of the heirs, was established in the Roman law in order to protect the creditors' interests from the negligent and insolvent heirs. This institute prevented the intermingling of the inherited part of the estate with the property of the heir, so that the deceased's creditors could settle their claims before the insolvent heir's creditors. Due to its importance and significance in relation to legal certainty, this institute has been accepted in modern inheritance laws. In this paper, the authors analyze the institute separatio bonorum and its non/application in practice with the purpose of making suggestions for overcoming the existing problems in relation to providing greater protection to creditors.
\end{abstract}

Keywords: deceased, estate, heirs, creditors, separatio bonorum.

\section{Introduction}

With the occurrence of death, the legal subjectivity of the deceased ends, the succession (delatio hereditas) is opened and his/her property rights and property obligations, are transferred to the heirs (heres) by law. If the 
deceased is indebted, the position of his/her creditors becomes uncertain, as it depends on the distribution of the estate to the heirs. The danger becomes greater when the heir himself/herself is indebted. With the opening of the succession "the estate intermingles with the property of the heir, and the heir becomes the titular of the entire property, the one he/she had before the deceased's death and the one he/she inherited (Djordjevikj, 1997, p. 344. )." In this case, the heir's creditors see a favorable opportunity to settle their claims from the estate. If the inherited part of the estate becomes intermingled with the property of the heir, the deceased's creditors may be deceived and prevented from exercising their rights. In Roman law, this possibility was introduced by the Roman praetors who, in order to protect the deceased's creditors from the negligent and insolvent heirs and their creditors, established the institute separatio bonorum (D.42.6.1.18 Gaius D.4.4.7.5.Ulpianus). According to it, "the deceased's creditors could request both properties to remain separate until their claims have been settled (Nicholas, 2009, p.239)." Thus, the deceased's creditors were protected from the heirs' disposal until their claims were settled from the separated estate.

The institute separatio bonorum is an integral part of modern inheritance laws (Ruggeri L., Kunda I., Winkler S, 2019, ; Garb L, 2004), including the Macedonian inheritance law (Mickovikj D. \& Ristov A, 2020). Despite being prescribed by law, this institute does not work in practice and is accompanied by numerous problems. The deceased's creditors find it very difficult to settle their claims (Horvat M, 1977, p.336-337, Romac A, 1981, p.389). Considering the fact that no attention has been paid to this important issue in the domestic legal science so far, it has become necessary to analyze the problems in practice which have arisen from the vague and outdated legal solutions that call into question the legal certainty in property relations (Ristov A, 2016).

\section{Separatio bonorum in Roman law}

The separation of the estate, i.e. the inherited part from the heir's property is an institute that dates back to Roman law, and is known as separatio bonorum or beneficium separationis (Puhan I, 1973, p.457). It emerged as a result of the need to resolve situations where the estate was in assets and the heir was over-indebted. In that situation, the creditors could not be certain that they would settle their claims if the estate became intermingled with the overindebted heir's property. Based on this institute, the deceased's creditors received a guarantee that the inherited part of the estate would not be intermingled with the heirs' property until their claims were settled.

In Roman law, debts along with property rights were an integral part of the estate. The heir was responsible for the payment of the deceased's debts up to the value of the inherited part. If there were several heirs, they paid the debts in proportion to the value of their inherited parts, unless the deceased had 
determined otherwise in his/her will. Even then, the payment of the creditors' claims was accompanied by difficulties due to which the institutes separatio bonorum (Puhan I., Polenak Akjimovska M., Buchkovski V. \& Naumovski G, 2014, p.366) and beneficium inventaria (Borkovski E. \& Plesis P.D, 2009, p.229) were introduced. According to the principle of universal succession (universitas rerum) inventaria (Borkovski E. \& Plesis P.D, 2009, p.230), the deceased's estate was intermingled with the heir's personal property. Based on that, there was a possibility that the deceased's creditors, as well as the legatees, could suffer damage by the heir who was over-indebted and insolvent. For that reason, the praetors allowed the creditors to claim separatio bonorum, the separation of the inherited part from the heir's personal property. This possibility allowed the deceased's creditors to settle their claims from the inherited property before the heirs' creditors, who could only settle their claims from the residue of the estate (Andreev M. N, 1958). It prevented the intermingling of the inherited part with the property owned by the heir (Andreev M. N, 1958).

Separatio bonorum made it possible for the inherited property to be kept separate from the heir's personal property, in order for the deceased's creditors to settle their claims in full from the estate, before the heir's creditors. The deceased's creditors were given priority in the settlement of claims over the heir's creditors. In Justinian's time, the creditors had the right to settle their claims to the estate within five years. The separation from the heir's property was not possible if the heir had already sold the estate conscientiously

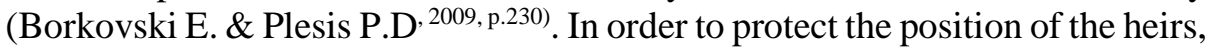
Justinian introduced the institute beneficium inventarii, known as benefit of the inventory (Borkovski E. \& Plesis P.D, 2009, p.230). The heir's obligations were limited to the assets of the estate, provided that he/she made an inventory of the estate. The inventory had to be initiated within one month and finished within three months of the person finding out that he/she has become an heir. The inventory was supposed to be conducted in front of witnesses (Borkovski E. \& Plesis P.D, 2009, p.230).

\section{Separatio bonorum in comparative law}

The reception of Roman private law (Nikolikj D, 2004, p.72-93) contained in Justinian's codification Corpus Iuris Civilis (Pop Georgiev D, 1966, p.11-12), began with the development of commodity-monetary relations in the Middle Ages. Roman law later became part of "the foundation of all great bourgeois civil codifications (Pop Georgiev, 1966, p.11-12)." Besides being a part of the old civil codifications (Ruschev I, 2019, p.149-183), the institute separatio bonorum became an integral part of modern inheritance legislations and newer civil codifications (Garb L., 2004, Stojanovikj N., 2006, 15-22). Given the fact that inheritance law is closely connected with tradition, customs and national culture, there are no uniform solutions (Ristov A, 2012) in comparative law, not even in relation to the separatio bonorum institute. This is especially evident in regard to the solutions related to: the mandatory 
summoning of creditors, what the estate consists of (movable or immovable property), the time limits, the start of the time limit, the length of the time limit in which the separation of the estate may be requested and the persons who have the right to request separation (Gottwald P., Schwab D. \& Buttner E., 2001).

Despite the close and former common legal tradition (Blagojevikj B.T, 1983), differences have appeared in the inheritance legislations of the countries from the former Yugoslav territories in the past decades (Antikj O. \& Balinovac Z. M, 1996). Under the influence of the Federal Law on Inheritance ${ }^{1}$ of 1955, besides being a part of the Macedonian inheritance law, this institute is without any changes, also a part of the inheritance legislations of Slovenia ${ }^{2}$, Republic of Srpska ${ }^{3}$ and Kosovo ${ }^{4}$. Some additions have been made in the Law on Inheritance of Serbia, that if the items and rights were at the heir's disposal up to the point of separation of the estate, then the disposal of those items and rights would remain valid (art. 225 para. 2$)^{5}$ It is further provided that the heir's creditors cannot be settled from the separated estate until the claims of the deceased's creditors who requested the separation have been settled (art. 226) (Djurdjevikj D. B, 2017). In the Law on Inheritance of Montenegro, the provisions on separatio bonorum have been supplemented by the creditors' obligation to make their claim probable as well as the danger that without the separation of the estate they cannot settle their claim (Article 141 para. 1) ${ }^{6}$.

The institute of separation of the estate from the heir's property is best regulated in the Law on Inheritance of Croatia. All issues related to the separatio bonorum institute are regulated in detail in the Croatian inheritance law. Article 140 stipulates that: (1) The deceased's creditors may request for the estate to be separated from the heir's property within three months from the opening of the succession, if they make the existence of the claim probable as well as the danger that without separation they cannot settle their claim.

(2) In that case, the heir cannot have the items and rights from the estate at his/her disposal, nor can his/her creditors settle their claims from them, until the creditors who requested the separation have settled their claims.

(3) The deceased's creditors who requested the separation can settle their claims only from the assets of the estate.

(4) The court may appoint a guardian for the separated estate.

(5) At the request of the deceased's creditors, the court may order guardianship of the separated estate. The costs for the guardianship of the estate are borne by the creditors who requested it.

\footnotetext{
${ }^{1}$ Uradni list RS [Official Gazette of Republic of Slovenia], 67/01.

${ }^{2}$ Službeni glasnik RS [Official Gazette of Republic of Serbia], 46/95, 101/203

${ }^{3}$ Čl. 164, Službeni glasnik R. Srpske [Official Gazette of Republic of Srpska], 1/2009

${ }^{4}$ Zakon o nasleđivanju Kosova [Law on inheritance of Kosovo] br.2004/26

${ }^{5}$ Službeni glasnik RS [Official Gazette of Republic of Serbia], br.46/95, 101/2003

${ }^{6}$ Zakon o nasleđivanju, Službeni list Crne Gore [Law on inheritance, Official Gazette of Republic of Montenegro] 74/08
} 
(6) If the creditor who requested the separation does not have an enforcement document or if he/she has not previously initiated proceedings for the settlement of his/her claim, he/she is obligated to initiate proceedings for the settlement of the claim, within a time limit set by the court with the decision for separation of the estate. If the creditor does not initiate the proceedings to which he/she has been instructed, within the prescribed time limit, the court will ex officio annul its decision on the separation of the estate.

(7) The court decides on the creditor's request by issuing a decision in a succession proceedings. Appealing that decision does not delay its application. The same provisions are prescribed in their entirety in the Law of the Federation of Bosnia and Herzegovina (Article 173) ${ }^{7}$.

\section{Separatio bonorum in Macedonian law}

The institute separatio bonorum, separation of the inherited part (estate) from the heir's property has existed in the Macedonian inheritance law since the creation of this institute (Spirovikj Trpenovska Lj., Mickovikj D. \& Ristov A, 2010). It was first defined in Article 146 of the Federal Law on Inheritance of $1955^{8}$, according to which:

"The deceased's creditors can request separation of the estate from the heir's property within three months from the opening of the succession.

In that case, the heir cannot have the items and rights from the estate at his/her disposal, nor can his/her creditors settle their claims from them, until the creditors who requested separation have settled their claims.

The deceased's creditors who requested this separation can settle their claims only from the assets of the estate.

The court may appoint a guardian for the separated estate."

The same provision was used in its entirety in the first republic Law on Inheritance ${ }^{9}$ from 1973 (Article 145). After the proclamation of independence, the legislature took the solutions from the previous regulations, including the provision governing the institute separatio bonorum (Article 137) and used them in the Law on Inheritance of $1996^{10}$, with minor changes.

The legislature used multiple provisions from other laws (Family Law, Housing Law, etc.), including the provisions from Articles 137-143 of the Law on Inheritance, which include the institute of separation from the estate, in the Law on Property and Other Real Rights ${ }^{11}$ that was enacted in 2001. With this wrong move, the legislature violated the entirety of several legal texts, including the Law on Inheritance, which omitted the inheritance agreements. They found their place in the Law on Obligations of 2001. Instead of following

\footnotetext{
${ }^{7}$ Službene Novine FBiH [Official Gazette of Federation of Bosnia and Hercegovina] $80 / 14$

8 "Official Gazette of the FPRY" No. 20/55, 12/55 and 42/65

9 "Official Gazette of the SRM" No. 35/73 and 27/78

10 "Official Gazette of Republic of Macedonia" No.47/96.

11 "Official Gazette of Republic of Macedonia" No.18/01, 92/08, 139/09 and 35/10.
} 
the example of the Family Law ${ }^{12}$ of 1992, which created a "mini codification" of the regulations in the field of family law and the proceedings in marital and family disputes, the legislature did the opposite when it came to the Law on Inheritance! That took the legal unity apart and thus violated its regulating essence. This inconsistent approach and mistake can be corrected by the legislature if the Civil Code is adopted (Galev G, 2009).

Undoubtedly, the legal certainty in legal transactions is one of the most important arguments that made the legislature include this institute in our inheritance law (Ristov A, 2018). However, these provisions raise more questions related to their non/implementation in practice. The difficulties faced by creditors in Roman law still plague creditors today. The legal provision that has been unchanged for decades, as well as the non-compliance and inefficiency of other provisions in practice, create a number of dilemmas and problems in practice. Moreover, these dilemmas have arisen from the legal reforms in the judiciary, on the basis of which certain competencies of the courts were transferred to notaries and enforcement agents as persons with public authority. In reference to that, the dilemma as to who is competent to act upon the request for separatio bonorum emerged in practice!

Despite the clear provisions, the realization of the institute separatio bonorum is very difficult in practice for several reasons. First, the legal time limit of three months from the death of the deceased to apply for the separation of the inherited part from the heir's property is very short. This is a preclusive time limit of which the creditors are not very informed and as a result of ignorance of the law they often miss it (ignorantia iuris nocet et neminem excusat).

Second, the realization of the institute separatio bonorum depends on the creditors finding out about the death of the deceased. How will the creditors request separation of the estate from the property of the heir within three months from the death of the deceased when there is no legally regulated way of public information about the death of a certain person. The creditor cannot read the obituaries every day or constantly ask the neighbors! The probability of missing the preclusive time limit is high.

Third, in many cases the registrar does not comply with the legal obligations. In the succession proceedings, as official proceedings, the registrar is obligated to submit a death certificate to the court within 30 days from the death of a person. However, he/she does not have a legal mechanism to force the heirs to provide the necessary information. There is no system of connection between the Office for management of registers and the Agency for Real Estate Cadaster, enforcement agents and notaries. Due to the immense grief for the loss of a loved one, religious beliefs, and other reasons, the heirs do not provide complete information to the registrar. The registrars submit death certificates with incomplete information to the courts, which transfer the burden of this

12 "Official Gazette of Republic of Macedonia" No. 80/1992, 9/1996, 38/2004, 33/2006, $84 / 2008,67 / 10,156 / 10,39 / 12,44 / 12,38 / 14,115 / 14,104 / 15$ and $150 / 15$ 
difficult task to the notaries ${ }^{13}$. In the meantime, there is a possibility of "scattering" of the more valuable items.

Fourth, in Macedonian, unlike in others, there is no legal time limit within which the estate should be distributed after the death of the deceased. Moreover, when the heirs know that the deceased was indebted, they deliberately do not initiate succession proceedings before the court.

Fifth, the Law on non-litigation proceedings does not prescribe the possibility for the succession proceedings to be initiated by the heirs or creditors. The court considers the proposal submitted by these persons as an initiative to start the succession proceedings. In that sense, a need arises for the creditors to have the right to submit a proposal for initiation of succession proceedings.

Sixth, given the fact that the request for separation of the estate is submitted to the court by the creditors, does that also imply a request for a temporary measure for prohibition on disposal of the estate (inherited part) of the heir or does the request for separation itself imply the prohibition on disposal. The legal provisions do not explicitly prescribe, nor does the law refer to the proper application of the Law on Securing Claims. Despite this, there is no other way to separate the inherited part from the other property of the heir. The decision on separation of the estate and the temporary measure for prohibition on disposal and alienation of the inherited part will enable the deceased's creditors to settle their claims from the estate.

Seventh, given the short time limit for submitting the request for separatio bonorum, the question arises as to what will happen if the legal time limit of three months expires. In such a case, given the preclusive nature of the legal time limit, the creditors will lose the right to request separation of the estate from the heir's property and the opportunity to settle their claims from it. After the distribution of the estate, they will be able to settle their claims from the heirs' property together with the other creditors.

Eighth, based on the decision prescribing a temporary measure for prohibition on disposal of the estate, the heir will not be able to have at his/her disposal the separated estate, nor will his/her creditors be able to settle their claims until the estate creditors have settled their claims. For that purpose, the legislature provided the possibility for the Court to appoint a guardian for such an estate. The numerous questions and problems regarding the application of these provisions indicate the need for a more thorough regulation of this issue so that it works in practice without any problems.

In contrast to the separatio bonorum institute, there is a point of view in theory that "creditors can request the settlement of their claims immediately after the succession has been opened, without waiting for the estate to be distributed (Chavdar, 1996, p.290)." This point of view is related to the distinction between gross and net estate that the legislature makes within the Law on Inheritance. Namely, according to the legislature, only when the

${ }^{13}$ See conclusion from a joint meeting of the Ministry of Justice, the CNRM and the Office for management of registers of births, marriages and deaths. 
deceased's debts, the costs for inventory and appraisal of the estate, as well as the costs for burial of the deceased have been deducted from the gross value, the net value of the estate will be determined. The net value of the estate is specifically the subject of distribution among the heirs. Therefore, according to this point of view, in case the creditor submits such a request, if possible, the notary public will be obligated to set aside that part of the estate so that the creditor/s can settle their claims from it.

Having in mind the principle of universal succession, i.e. that the heirs inherit the estate in its entirety, with all its property rights and obligations, we think that this point of view is not acceptable. This is due to the fact that the concept of succession by law, ex iure, at the moment of the deceased's death when the estate (property rights and obligations) is transferred to the heirs is accepted in Macedonian inheritance law. Otherwise, the concept of a lying estate (hereditas iacens) should be accepted, according to which the estate is considered as a separate legal entity until the heirs give a positive succession statement. The principle that a property cannot exist without a possessor is accepted in Macedonian law (Grupce A, 1983). Therefore, the estate belongs entirely to the heirs from the moment of the deceased's death.

According to the current legislation, separatio bonorum, i.e. separation of the estate from the heir's property, can only be determined by the succession (non-litigation) court by a decision. The court can issue a decision on separatio bonorum within three months from the opening of the succession at the creditors' request, regardless of whether the succession proceedings have been initiated or not. The creditor requesting the separation of the estate is not obligated to prove that he/she has a claim against the deceased. He/she only needs to make his/her claim probable to the court. In such a case, the court will obligate the creditor to initiate court proceedings within a certain time limit, in which the existence of the creditor's claim will be established. If the creditor misses the time limit, then the heirs can ask the court to annul the decision on separation of the estate and the temporary measure for prohibition on disposal and alienation of the estate. If the creditor has an enforcement document for his/her claim against the deceased, the adoption of the decision on separation of the estate will be significantly easier for the court.

The court decision on the separation of the estate plays the role of a temporary measure for securing the claims. The purpose of this decision is to prevent the intermingling of the estate with the heir's property and to ensure the settlement of the claims of the deceased's creditors. Therefore, the provisions of the Law on Securing Claims will be appropriately applied in the proceedings. In theory, the creditor requesting the separation of the estate is called a separatist (Djordjevikj V. Dj, p. 344). Separation as well as an inventory and appraisal of the estate will be determined in the decision by the court. The court may, but is not obligated to appoint a guardian to take care of the separated estate.

The heir is liable for the deceased's debts only up to the value of the items and rights that he/she has inherited (cum viribus hereditatis). As long as the decision on separation of the estate is valid, the heir cannot have at his/her 
disposal the inherited part of the estate, neither legally nor factually. If real estate is included in the separated estate, it is necessary for the decision and the prohibition on disposal and alienation to be noted in the Real Estate Cadastre. If the heir acts contrary to the abovementioned, then he/she is liable for the damage he/she has caused. Also, there is a possibility of criminal liability for non-compliance with the court decision.

The deceased's creditors can settle their claims only from the separated estate stated in the court decision which the notary public should note in the succession decision. If the creditors' claims are settled or secured in another way by the heirs (pledge, surety, etc.) there will be no more reasons for the existence of the decision on separation of the estate. Based on that, the court will annul the decision on separatio bonorum and other security measures that have been determined in that regard.

What happens if the deceased has died during the enforcement proceedings? According to the Law on Enforcement ${ }^{14}$ of 2016, if the party or his/her legal representative dies during the enforcement proceedings, the enforcement is terminated (Article 30 paragraph 1). In such cases, when the enforcement agent learns about this information, it is necessary for him/her to confirm it with a death certificate. He can obtain this information from the heirs or from the Office for Management of registers. The enforcement agent is obligated to inform the party's heirs about the termination of the enforcement, if they and their place of residence or stay is known, as well as to inform the opposing party (Article 30, paragraph 2). In such a case, having in mind the short preclusive period of three months from the death of the deceased for the creditors to submit a request for separation of the estate from the heir's property, the enforcement agent is obligated to inform the creditor about this right. Otherwise, the creditor will lose the opportunity for separation of the estate from the heir's property, which will complicate the proceedings and the probability of settling his/her claim. This will further complicate the enforcement proceedings.

According to the legal provisions, if no ex officio succession proceedings have been initiated, and the heirs have not submitted a proposal for succession proceedings within 60 days from the day when the debtor's death occurred, i.e. from the day the court decision for declaring the missing person dead has become enforceable, or their place of residence is not known, the enforcement agent will without any delay ask the Social Work Center to appoint a temporary guardian to the heirs in accordance with the Family Law.

Even though the legislature had good intentions, for the creditor's claim to be settled, having in mind the existing weaknesses and legal gaps in the legislation, this solution is barely or not applied at all in practice. This is due to the fact that the Social Work Center as a competent guardianship authority has a number of other competencies in the field of social protection, the procedure for adoption of children, supervision over the exercise of parental rights,

14 "Official Gazette of the Republic of Macedonia" no. 72/16 and 142 1/16 (cons. text) 26/18. 
proposal to the court to whom children should be entrusted for care and upbringing, conciliation procedure of spouses, maintaining the child's contacts with the noncustodial parent, domestic violence. In addition, a key problem is also the lack of staff and the inability to act in accordance with this legal provision in smaller areas.

The experience so far shows inconsistency in Social Work Center's actions. Namely, in most cases the Social Work Center does not provide an answer to the request, while in a small number of cases the answer is that a guardian cannot be appointed, due to people's lack of interest for guardianship. The key problem in this situation is the fact that according to our law, guardianship is based on a voluntary basis. In a capitalist society, the outdated socialist solution for guardianship on a voluntary basis, is very difficult to apply.

The next question that arises is whether the Law on enforcement causes changes in the process of initiation of the succession proceedings from the Law on non-litigation proceedings. Is such a solution substantiated or should the changes be made in this law as well? There are also dilemmas about the type of authorization a guardian will have if he/she is appointed. Could the temporary guardian give a positive succession statement on behalf of the heirs? Legal certainty in property relations undoubtedly requires this in order to avoid abuse by the heirs. Should not the appointment of a temporary guardian be requested by the creditor, instead of the enforcement agent?

The large number of questions indicates the need for detailed regulation of this issue in Macedonian legislation. Moreover, information obtained by the enforcement agents confirms that this provision is not applied in practice. Who can make the Social Work Center, as a guardian authority, to effectively fulfill its obligation that has been prescribed by the Law on Enforcement. Having this in mind, a conclusion is inevitably imposed that systemic and thorough solutions which affect both material and formal law in order to achieve greater security in the settlement of creditors in case of death of the debtor are needed.

Aside from coming up with solutions in relation to the creditor of the estate, it is also necessary to come up with solutions in Macedonian law regarding the protection of the heir's creditors, who in order to deceive them and avoid the settlement of their claims, fictitiously or falsely renounces the inherited part. Unlike comparative law which regulates this issue in detail, there is a legal gap in Macedonian legislation (Mickovikj D. \& Ristov A, p.211). In this case, the only available option to the heirs' creditors is the Actio Pauliana, a lawsuit for challenging the debtor's legal actions. However, in practice it is rare for creditors to use this lawsuit in the context of succession.

\section{Separatio bonorum in case law}

The institute separatio bonorum is very rare in Macedonian case law which is not synchronized in terms of its application (Kostadinova Angelova I, 2019, p.82-88). The case law does not have a unified position in terms of competence when it comes to acting upon a creditor's request for separation of 
the inherited part from the heir's property (Kostadinova Angelova I, 2019, p.8288). In some cases the court acted upon the creditor's request for separatio bonorum, while in others the court held the position that the notary public should be the one to act upon the request in question (Kostadinova Angelova I, 2019 , p.82-88). We believe that the legal provision regarding this issue is clear and the only authority competent to decide on the separation of the estate is the court. This is due to the fact that the legal provision regulating this issue has not been changed for decades, from its introduction in the inheritance legislation until today. Although notary publics are trustees of the court when it comes to the succession proceedings, they do not have the authority to decide on the separation of the estate and temporary measures for prohibition on the disposal of the estate, in order to settle the claims of deceased's creditors. Therefore, we believe that only the court is competent to decide on separatio bonorum.

One or more creditors may submit a request to the court for separation of the estate. If the debtor has died during the enforcement proceedings for forced settlement of a claim, only the creditor has the right to submit a request for separation of the estate. The enforcement agent as a person with public authority, who acts upon the creditor's request has no right to submit a request for separatio bonorum. Only the creditor has that right. In order to produce legal effect, the request must be submitted within three months from the opening of the succession.

Given the fact that the legal provisions do not explicitly prescribe the form of the claim, there are two interpretations in the case law (Kostadinova Angelova I, 2019, p.82-88). According to the narrower, restrictive interpretation, only the person who has an enforcement document that determines his/her claim has the right to request separation(Kostadinova Angelova I, 2019, p.82-88). According to the broader, extensive interpretation, every person who has a claim against the deceased has the right to request separation of the estate from the heir's property. It is not required to have an enforcement document. It is only necessary to make the claim probable. According to the case law, making the claim probable implies some degree of certainty regarding the existence of a debtor-creditor relationship between the creditor and the deceased debtor. Regarding this point of view, we believe that the case law has properly accepted the broader interpretation. This is in accordance with the basic rules of logical legal interpretation, to accept what is more favorable in dubio pro reum.

Two situations may arise in case law regarding the second broader interpretation. The first situation is when the creditor has initiated proceedings before a competent authority (court or notary), but the proceedings have been terminated due to the death of the debtor. In such a case, the proceedings will continue after the decision for distribution of the estate becomes enforceable. The second situation is when the creditor has not initiated proceedings during the deceased's life, but he/she has requested separatio bonorum after his/her death. In this case, according to the case law, the creditor should be instructed to initiate appropriate proceedings with analogous interpretation of the 
provisions of the Law on Securing Claims, in order to prevent possible abuse by prohibiting the heir to have at his/her disposal the separated estate (Kostadinova Angelova I, 2019, p.82-88).

In cases when the creditor has not initiated proceedings for determining his/her claim, the heir may request annulment of the decision on separation of the inherited part from the heir's property and removal of the prohibition by analogous interpretation of the provisions of the Law on Securing Claims, which refer to the securing of claims and revoking the temporary or preliminary measure (Kostadinova Angelova I, 2019, p.82-88).

In practice, a question arises on whether in case the value of the estate is greater than the creditor's claim, the separation can be limited to a part of the estate and to which part. This is due to the fact that during the proceedings the amount of the claim may increase because of interest, additional costs incurred in determining or settling the claim. Given the fact that the purpose of the institute separatio bonorum is to settle the creditors' claims, it would be unfair to limit the inheritance rights of the heirs (Kostadinova Angelova I, 2019, p.8288 ) by a total separation of the estate, in case when the estate is greater than the creditors' claims. The separation of the inherited part of the estate should be in the amount of the creditors' claim (Kostadinova Angelova I, 2019, p.82-88). It is our opinion that such point of view can only complicate the relationships by requiring the involvement of an appraiser in the proceedings and the possibility of challenging the value of the appraisal. Therefore, we believe that the separation should apply to the entire estate, in order to provide more efficient security to the deceased's creditors.

In case the estate for which the separatio bonorum is requested consists of real estate, the decision for separation of the inherited part from the heir and the prohibition on disposal need to be registered in the Real Estate Cadastre. In this case, if another creditor later appears with a request for separation of the inherited part from the heir's property, then the rules of priority apply (Kostadinova Angelova I, 2019, p.82-88).

Also, the following question may arise in practice: can a separation of the estate be requested for just a part of the heirs? In situations when the heirs inherit an ideal part of the estate, it is not possible to separate the estate for just a part of the heirs, i.e. such a request should be directed toward all heirs. The failure to submit a request for separation of the estate is not an obstacle for the realization of the opportunity to request the settlement of the claim from the heirs of the deceased, in the amount of the inherited part in litigation proceedings.

\section{Instead of a conclusion - separatio bonorum de lege ferenda}

Having in mind the numerous problems in practice related to the realization of the rights of the creditors when a person dies, there is an inevitable need to supplement the legislation that regulates the institute separatio bonorum. Detailed changes are also needed in other regulations related to succession. This will contribute to the increase of legal certainty in property 
relations and the exercise of the creditors' rights. In the forthcoming inheritance law reform, it is necessary for the legislature to put the provisions regulating the separation of the estate back within the framework of the inheritance legislation. In addition, the separatio bonorum institute needs to be refined and supplemented in order to avoid and overcome the current dilemmas and problems in practice. The legal provisions should explicitly prescribe that the creditors should submit the request for separation of the estate to the succession court. It is necessary for the legislature to extend the preclusive time limit for submitting the request for separation of the estate to one year from the person's death. This will contribute to a greater protection of the creditors in the settlement of their claims. The legal provisions need to be supplemented by prescribing the conditions that allow this security measure. It should be the creditor's obligation to make the existence of his/her claim probable and the danger that without separation he/she would not be able to settle the claim. With the decision for separation of the estate from the property of the heir, the court will prohibit the heir from disposing of and alienating the inherited part and will request an inventory and appraisal of the estate. It is also necessary to prescribe a provision on the basis of which, the court may order guardianship for the separated estate at the request of the deceased's creditors. The costs for guardianship of the estate would be borne by the creditors who requested it. In case when the creditor who requested the separation does not have an enforcement document or if he/she has not previously initiated proceedings for the settlement of his/her claim, he/she is obligated to initiate proceedings for the settlement of the claim within a time limit prescribed by the court with the decision for separation of the estate. If the creditor does not initiate proceedings to which he/she is referred within the prescribed time limit, the court will ex officio annul its decision for the separation of the estate. It is also necessary to regulate the cases when several creditors have simultaneously submitted a request for separation of the estate and the estate is not sufficient to settle their claims. In such cases, a provision should be prescribed according to which they will be able to settle their claims proportionately. Finally, an explicit provision is needed that the court decides upon the creditor's request by adopting a decision in a succession proceeding. An appeal against that decision does not delay its application. Aside from the protection of the deceased's creditors, it is necessary for the legislature to explicitly prescribe the protection of the heirs' creditors. In addition to refuting the debtor's statement by which he/she renounces the succession in order to deceive the creditors, it is necessary to provide the possibility for the heir's creditor to accept the succession on his/her behalf. 


\section{References}

Andreev M. N. (1958) Rimsko chastno pravo [Roman private law], Sofija: Nauka I iskustvo;

Antikj O. B. (1994) Nasledno pravo [Inheritance law], Beograd: Narodna Knjiga;

Antikj O. \& Balinovac Z. M. (1996) Komentar zakona o nasledjivanju [Commentary on the law of inheritance], Beograd;

Blagojevikj B.T. (1983) Nasledno pravo u Jugoslaviji, prava republika $i$ pokrajina [Inheritance law in Yugoslavia, law of the republic and the provinces], Beograd: Savremena administracija;

Borkovski E. \& Plesis P.D. (2009) Rimsko pravo [Roman law], Skopje: Prosvetno delo;

Carbonnier J. (2014) Gragjansko pravo [Civil law] Skopje: Ars Lamina;

Chavdar K. (1996) Komentar na zakonot za nasleduvanjeto [Commentary on the Law on inheritance], Skopje: Akademik;

Cheremnih G. G. (2009), Nasledstvenoe pravo uchebnik [Inheritance law textbook], Moskva: Rosijskaja akademija, advokaturi i notariata;

Fon Staudinger J. (2014) Gragjanski zakonik, Osnovi na gragjanskoto pravo [Civil Code], Skopje: Ars Lamina;

Galev G. (2009) Proekt za izgotvuvanje na Gragjanski zakonik [Project for drafting a Civil Code], Skopje

Garb L. (2004) International Succession, Kluwer Law International;

Grupce A. (1983) Imotno (Gragjansko) pravo, Opsht del [Property (Civil) Law, General part], Vtoro i izmeneto izdanie, Skopje: Kultura;

Gottwald P., Schwab D. \& Buttner E., (2001), Family and Succession Law, Wolters Kluwer;

Hadji Vasilev M. (1983) Nasledno pravo [Inheritance law] Skopje: Kultura;

Horvat M. (1977) Rimsko pravo [Roman law], Zagreb;

Didier G. (1999) Successions Libéralités [Successions Gifts], Paris: Éditions Dalloz, Armand Colin;

Djordjevikj V.Dj. (1997) Nasledno pravo [Inheritance law], Pravni fakultet Nish;

Djurdjevikj D. (2009) Aktuelna reforma naslednog prava u Crnoj Gori [Current reform of the inheritance law of Montenegro], Anali Pravnog fakulteta u Beogradu, br. 1/2009, Beograd;

Djurdjevikj D. B. (2017), Institucija naslednog prava [Institutions of inheritance law], Pravni fakultet, Beograd: Nomos;

Kadikj Lj. (2008) Osvrt Predlog Zakona o nasledjivanju Crne Gore [Review of the Draft Law on Inheritance of Montenegro] Zbornik Pravnog fakulteta u Podgorici, In memoriam prof. d-r Branislav Tomkovikj, br. 38, Podgorica;

Kerridge R., Brierley A. H. R, Hughes D. P., (2008) Parry \& Kerridge The Law on Succession, Thomson Reuters;

Klarikj P. \& Vedrish M. (2006), Gradjansko pravo, Opchi dio, stvarno pravo, obvezno i nasljedno pravo [Civil law, General part, property law, law 
on obligations and inheritance law], $\mathrm{X}$ izdanje, Zagreb: Narodne Novine;

Kostadinova Angelova I. (2019), Sudskata praksa i problemite vo ostavinskata postapka pri oddeluvanjeto na nasledniot del od imotot na naslednikot [The case law and the problems in the succession proceedings during the separation of the inherited part of the property of the heir] Notarius, no. 36: Skopje NCRSM;

Mickovikj D. \& Ristov A. (2020) Nasledno pravo [Inheritance law], Skopje: Univerzitet Sv.Kiril I Metodij;

Mickovikj D. \& Ristov A. Reforma vo naslednoto pravo [Reform in the inheritance law;

Nicholas B. (2009) Voved vo rimsko pravo [An introduction to Roman law], Skopje: Prosvetno delo;

Nikolikj D. (2004) Uvod u system gradjanskog prava [Introduction to the civil law system], Novi Sad;

Place M-H., Cauchois le Mière P., (1993), Guide pratique de la transmission du patrimoine en Europe [Practical guide to the transmission of inheritance in Europe], Paris: Editions, Litec;

Pop Gergiev D. (1966) Gragjansko pravo [Civil law] Univerzitet vo Skopje;

Puhan I. (1973) Rimsko pravo [Roman law], Skopje: Univerzitet Sv.Kiril I Metodij;

Puhan I., Polenak Akjimovska M., Buchkovski V. \& Naumovski G. (2014) Rimsko pravo [Roman law], Skopje: Praven fakultet;

Ristov A. (2012), Harmonizacija naslednog prava u EU, Revija za Evropsko pravo [Harmonization of Inheritance Law in the EU, European law magazine], Kragujevac: Udruzhenje za Evropsko pravo;

Ristov A. (2016) Pravnata ne/sigurnost vo makedonskoto semejno i nasledno pravo, [Legal insecurity in Macedonian family and inheritance law], Ohrid School of law, Vol. 3, Skopje: Iuridica Prima;

Ristov A. (2018) Zashtita na pravata na doveritelite vo makedonskoto nasledno pravo: dekor ili chekor kon vladeenjeto na pravoto [The protection of the rights of the creditors in the Macedonian inheritance law: a decorum or a step towards the rule of law], Ohrid School of law Vol. 8, Skopje: Iuridica Prima;

Romac A. (1981) Rimsko pravo [Roman law], Zagreb;

Ruggeri L., Kunda I. \& Winkler S. (2019) Family Property and Succession in the EU Member States, Sveuchilishte u Rijeci;

Spirovikj Trpenovska Lj. (2009) Nasledno pravo [Inheritance law], Skopje: 2 Avgust-S;

Spirovikj Trpenovska Lj., Mickovikj D. \& Ristov A (2010) Naslednoto pravo vo Republika Makedonija [Inheritance law in the Republic of Macedonia], Skopje: Kulturna ustanova "Blesok";

Spirovikj Trpenovska Lj. Mickovikj D. \& Ristov A. (2011) Nasleduvanjeto vo Evropa [Succession in Europe] Skopje: Blesok;

Stojanovikj N., (2006), Separatio Bonorum in Contemporary Law, Facta Universitatis, vol. 4; 
Stojanovikj N. (2011) Nasledno pravo [Inheritance law], Univerzitet u Nishu, Pravni fakultet Nish;

Tasev H. (2006), Blgarsko nasledstveno pravo [Bulgarian inheritance law], осмо издание, Sofija: Nova redakcija, Petkanov G., Tasev S. Siela;,

Tratnik M. (2003) Civilno pravo Zbirka predpisov [Civil law collection of regulations] Maribor: Codex Iuris;

Zupanchikj K. (2002) Dedovanje z uvodnim pojasnili [Inheritance with introductory explanations], Ljubljana: ČZ Ur. List RS. 